\title{
Visual precedence: theoretical and applied aspects
}

\author{
Leyla Mardieva ${ }^{1 *}$ \\ ${ }^{1}$ Kazan Federal University (Kazan Federal University (KFU), Kremlyvskaya Str., 18, Kazan, \\ 420008, Russian Federation
}

\begin{abstract}
The article focuses on scientific publications dedicated to visual precedence. The analyzed works reflect a certain irregularity in the terminological designation of precedent visual phenomena (pre-existing visual phenomena - PVP) and, at the same time, the replenishment of terminological vocabulary in studies of the researchers dealing with visual precedence. A review of works on the declared topic highlights the lack of unanimous opinion on the PVP representation forms in text structures and on the scope of visual precedence. The specific features of the PVP functioning in political and media discourses have been definitively described by the beginning of the 2 nd decade of the 21st century; although fragmentary but sufficiently representative information has been obtained about the nature of their existence in advertising; the first steps were being taken in studying of their specific use in artistic and popular science discourse. The researcher s have established sphere sources of PVP, their general and particular functions, described technologies for associative increments actualization through PVP, exciting meanings planned by the addressing speaker. The results of the PVP study are reflected in the forensic linguistic examinations practice and in language teaching at school and the university.
\end{abstract}

\section{INTRODUCTION}

Active invasion of visual forms of information storage and transmission into almost all spheres of human communication (not only artistic and mass media, but also everyday and scientific) leads to the need in formation of new methods of researching the products of communicative activity, where lingua-centered conservatism is giving way to the synergy of methodologies common for humanities; polycode texts become the object of linguistics, the meaning of which gives rise to the interaction of at least two semiotic systems, in particular, the natural language and the iconic language. At the same time, both the iconic code system and the natural language are able to translate the signs of other semiotic systems, to appeal with the help of the precedent visual phenomena (PVP) to the cultural memory of the society.

\section{Methods}

Basing on application of general scientific descriptive methods of analysis and comparison, the article studies works devoted to pre-existing visual phenomena.

Precedent visual phenomena are cognitively and culturally significant, emotionally colored, and constantly replicated visual images of the cultural space materialized in the text

\footnotetext{
* Corresponding author: layka66@mail.ru
} 
$[1 ; 2]$. PVP are actively studied by modern scientists (M.B. Voroshilova, V.E.Chernyavskaya, E.V. Babich, M.R. Babikova, L.V. Dubovitskaya, O.N. Gorbacheva, V.A.Kameneva, Yu.B . Pikuleva, T.P. Romanova, R.T. Saduov, K.A. Kondratyuk, E. A. Ronina, A.V. Dmitrieva, M.V. Golomidova, L.P. Amiri, S.A. Gerasimova, N.N. Volskaya, Yu.I. Detinko, R.I. Grigorieva, T.F. Petrenko, M.B.Slepakova, and others), researching polycode (multimodal) texts.

\section{Results}

Precedent visual phenomena are the new object of linguistic research. It is therefore natural that at present we are witnessing a certain terminological disorder in this area of scientific research. In addition to the term precedent visual phenomenon, the following generic terms: iconic precedent phenomena and visual quotes, visual intertextuality, visual allusions, and precedent text of a visual character, are used to denote these cultural signs. Researchers also introduce the following aspectual terms into scientific circulation: non-verbal quotes from movie fragments, precedent cultural signs from the field of architecture and sculpture, images of precedent realities, etc.

Visual precedence is understood both narrowly and broadly. With the narrow approach to visual precedence, the signs of an exclusively iconic nature, that is iconic primary texts (as a rule, film frames, drawings, sculptures or their fragments, graphemes, etc.), which have received iconic implementation in the secondary text, are recognized as such. With the broad approach, PVP include both verbal and non-verbal implementation forms of integral or fragmentary picture-like images of texts of any semiotic nature, including images of nonverbal behavior of individuals or social groups, images of the objective world as well as the external form, the structure of the iconic text, stored in the minds of members of a given sociocultural society. Mechanisms for the implementation of visual precedence in the latter case are characterized by their diversity; the precedent visual image can manifest itself nonverbally (in the iconic text), verbally and non-verbally, and even exclusively at the verbal level.

The range of phenomena attributed by scientists to visual precedence is noticeably expanding.

In recent years, architectural forms [3], national ornaments, graphemes, emblematic symbols, national cultural and social ideological markers [4] as well as images of famous writers, scientists, politicians, celebrities $[5 ; 6]$ are being included in PVP.

Scientists are inclined to attest "short-term elements of the cultural code" also as precedent phenomena of a new type (both verbal-visual and purely visual), the memes which "from a functional point of view are similar to ordinary precedent texts, but have a different structure and are characterized by a different, specific existence in the speech practice of Internet users" [7]. At the same time, there exists another point of view, according to which PVP are serving the basis for creating memes [8].

Both positions are valid: Internet users not only take advantage of the visual images that have become precedent, but also create visual images themselves, replicating them and turning them into precedent ones for a certain audience.

PVP are studied using a variety of methods:

1. The discursive-semiotic method make it possible to identify the main types (visual, verbal, verbal-visual) and iconic forms (photography, drawing, collage, etc.) of the visual precedence presentation, the features of pragmatic predestination and the distinctive features of PVP application in artistic, scientific - popular, advertising, political and media discourses. A discursive - semiotic analysis of the texts of nationalist associations enabled M.R. Babikova [9] to single out a special type of precedent - the "contextual precedent 
phenomenon", i.e. precedent (including visual) sign, whichappears as such (precedent) only in a specialized context intended for "its own" audience.

2. Functional and pragmatic method enabled to establish the following universal functions of PVP: attractive, meaning generating, emotional evaluative, influencing, ludic; and the specific functions: in advertising - image creating, prospection and retrospection function; character study, satirical, argumentative, delimiting, national and cultural identification; in artistic communication - overcoming textual lacunas; in the political sphere - figurative representation of a person, destruction of stereotypes and prejudices, modeling function, serving as a password, ludic function; in the caricature - satirical, historiographic and critical assessment of political actions.

In certain texts of Internet communications, PVP are able to create an atmosphere of informal friendly communication.

3. Methods of cultural linguistics applied by the scientists allowed them to outline the source study base (sphere-sources of citation, and in some cases specific primary texts) most actively used in a particular areas of communicative interaction or in the work of an individual writer, artist.

The source of citation is not only specific texts or genres, but also cultural phenomena of a certain historical epoch; these include, for example:

- Old Russian realities, "which in the past performed sacred functions: an Orthodox Church dome and a hip roof, a helmet of an ancient Russian warrior and a kokoshnik (headdress worn by Russian women) of a princess ... ornaments, amulets and attributes of ancient Russian clothing, a crown, a double-headed eagle and the Russian tricolor ... ancient Cyrillic graphics" [10];

- "Soviet cultural phenomena". Yu.B. Pikuleva emphasizes that the semantic feature of a 'Soviet' in the meaning implied in these PVP does not suppose the obligatory presence of pejorative semes; the semes 'ideologically marked', connotative increments, as the scientist puts it, "are induced by the context, and the evaluative sign of the precedent turns out to be floating, unstable" [11].

It is notable that the words "imaginary" and "false" are used quite actively in advertising; that is the images of precedent personalities and related situations are specially created by advertisers [12].

It should be noted that scientists classify PVP as visual stylistic means [13; 14 and more].

Among the productive technologies for updating the pragmatic functions of PVP are the following:

1) Various types of transformations of the initial PVP, including stylistic ones [15];

2) Visual blending - a mixture of cultural meanings from conceptually incompatible areas, which always has a maximum expression and, as a result, enhances attractiveness.

As an example of this technique, T.B. Radbil, A.I. Pomazov cite a meme in the form of Frederic Chopin's face (a precedent personality in iconic implementation), who is wearing pixel glasses from a meme popular in Russia - an image of a dog with glasses [16];

3) Metonymic transfer of the PVP meaning to an image, having no own precedent.

For example, the image of a girl on the Alyonka chocolate wrapper is PVP for Russians. The influence of this image is clearly seen on the new chocolate Kuzya the Alyonka's Friend wrapper with a boy in the style of the Soviet Alyonka" [17];

4) "Polyprecedence" is a stringing of precedent visual images.

M.R. Babikova cites the case of two sub-sphere-sources of the "Animation" and the "Political symbolism" combination in the nationalist discourse as an example of visual polyprecedence, namely:

a) Picture of a boy and a girl from a chewing gum inserts "Love is...";

b) "National flag of Germany", represented on cartoon heroes' clothes, and the precedent visual symbol "Coat of Arms of the Third Reich". 
Such combination gives rise to a new interpretation of "Love is...", to love is to throw zigs together [18].

PVP functioning in one or another form of discourse analysis is accompanied by an assessment of the results of their practical application, which can be adopted by imagemakers and political strategists, editors of newspapers and magazines, of Internet site developers, and taken into account in the linguistic examination of texts.

Among special works, including those of an applied nature, one shall first of all mention the M.R. Babikova's research [ibid]. The value of the author's work for the practice of forensic linguistic examinations in cases of inciting social, racial, national or religious discord and activities of prevention nationalism in the Internet is beyond doubt.

Studies carried out in the mainstream of intercultural communication are no less significant.

No doubt that many PVP are among the national precedents; their hidden meanings, associative increments, if used in a foreign cultural environment, are not realized, and therefore they need different methods of explication and interpretation [19].

PVP is also a tool which, along with the communicative competence, can successfully form the general cultural competence, and therefore is actively used in the practice of teaching Russian as a native language at school [20] and as a foreign language at the university [21].

\section{Conclusions}

Thus, at this stage of the scientific study of visual precedence:

1) there appeared monographic studies in which, along with other tasks, the problem of PVP functioning in the political, media, artistic discourses is posed and solved;

2) the conceptual and terminological vocabulary of the PVP researchers was replenished, the following new terms were introduced into scientific circulation: "contextual (visual) precedence phenomenon", "imaginary (false) PVP”, "visual blending", “(visual) polyprecedence", their definitions are given;

3 ) the practice of using PVP in different types of discourse is investigated;

4) a sufficiently voluminous picture of PVP functioning in polycode texts was obtained, giving an idea of which spheres-sources are the most often exploited for citing the PVP; what audience is the precedent visual image intended for; how and for what purpose it is used; what associations, stereotypes, concepts it is used to excite; what structural, semantic, stylistic changes (transformations) shall it be subjected to convey the meaning given by the sender and what technologies can be used to enhance the attractive, influencing and other functions of the PVP.

At the same time, issues related to the differentiation of a precedent and a symbol, with a change in the semiotic status of a precedent sign and its acquisition of the status of a symbol, still await their solution. The practice of using PVP in Internet discourse, in artistic, scientific and educational discourses is poorly studied. Special and more complete studies of the PVP application in practice of teaching languages at the universities and schools are also needed.

\section{Acknowledgments}

The work was performed according to the Russian Government Program of Competitive Growth of Kazan Federal University.

This paper was financially supported by the Russian Foundation for Basic Research, grant No. 20-012-22046. 


\section{References}

1. L. Mardieva, Social cultural reality and its interpretation in media texts. Integrative research experience, Kazan Kazan, Izd-vo Kazan. un-ta, 253 (2007) (in Russ.)

2. L. Mardieva, Pre-existing visual images and phenomena: a linguistic approach, in 3rd International Multidisciplinary Scientific Conference on Social Sciences and Arts SGEM 2016. Book 1. Vol. 3, 765-772 (2016).

3. T. P. Romanova, Ethnocultural marker in the Russian companies logos as a stimulus factor for the audience, URL: https://medialing.ru/ehtnokulturnyj-marker-v-logotipahrossijskih-firm-kak-reklamnyj-stimul-adresata/ (In Russ)

4. E.V. Babich, Communicative features of polycode artistic text (2017), URL: https://www.mgpu.ru/uploads/adv_documents/4052/1489663164032017BabichAkd.Pdf (In Russ)

5. O.N. Gorbacheva, V.A. Kameneva, Visual stylistic means in social internet advertising or the beginning of visual text stylistics, in Political linguistics, 2 (48), 124 - 127 (2014) (in Russ.)

6. A.V. Dmitrieva, M. V. Golomidova, Precedent Names of Historical Figures and Realities in Polycode Video Texts of Russian and French Political Advertising: Communicative and Pragmatic Aspect, in Nauchnyi dialog (Scientific dialogue), № 8, 25-40 (2019), URL: http://old.nauka-dialog.ru/assets/userfiles/6626/2540_Dmitrieva_Golomidova_ND_2019 8.pdf (in Russ.)

7. T.B. Radbil, A.I. Pomazov, Precedent Phenomena as Means of Establishing Attractiveness, in Polycode Internet Text. Vestnik Volgogradskogo gosudarstvennogo universiteta. Seriya 2, vol. 19, No. 1, 143 (2020) (in Russ.)

8. K.A. Kondratyuk, E.A. Ronina, Precedent visual image of american cinema as the basis of internet memes, in TSPU Bulletin. 4 (193),1032-1036 (2018) (in Russ.)

9. M.R. Babikova, M. B. Voroshilova, Contextual precedent phenomena as a way to represent nationalistic ideas, in Polinical linquistics, 6 (66), 58-63 (2017) (in Russ.)

10. T.P. Romanova, Ethnocultural marker in the Russian companies logos as a stimulus factor for the audience, in Media Linguistics, 5 (4), 521-533 (2018), URL: https://medialing.ru/ehtnokulturnyj-marker-v-logotipah-rossijskih-firm-kak-reklamnyjstimul-adresata/ (In Russ.)

11. Yu.B. Pikuleva, Precedent cultural signs of the Soviet era in commercial and political domestic advertising, Ekaterinburg (2008) URL: http://elar.urfu.ru/bitstream/10995/1828/2/Part2\%202008-12.pdf (in Russ.)

12. P. Amiri, Means of Visual Actualization as a Graphosemantic Variety of Language Game in the Creolized texts of Advertising Communication, URL: 
https://www.sgu.ru/sites/default/files/journals/izvestiya/pdf/2013/12/13/08_amiri.pdf (2013) (in Russ.)

13. N.N. Volskaya. Precedent Verbal and Visual Phenomena as the Basis for Historiography in Terebenev's ABC Book, the First Political Cartoon in Russia, No. 3 (2015), URL:

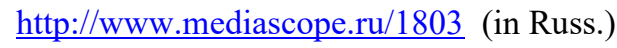

14. V. Shkurko, L. Mardieva, T. Shchuklina, M. Voroshilova, 'Perusal of verbal text through the lens of illustration', in National Academy of Managerial Staff of Culture and Arts Herald. № 3. 712-714 (2018).

15 V. Ju. Shkurko, L. A. Mardieva, T. Yu. Shchuklina, A. P. Chudinov, Poster images in a new linguistic and extralinguistic context, in Amazonia Investiga, vol. 7, № 12, 320-324 (2018).

16. T.B. Radbil, A.I. Pomazov, Precedent Phenomena as Means of Establishing Attractiveness, in Polycode Internet Text. Vestnik Volgogradskogo gosudarstvennogo universiteta. Seriya 2, vol. 19, No. 1, 148-150 (2020) (in Russ.)

17. P. Amiri, Means of Visual Actualization as a Graphosemantic Variety of Language Game in the Creolized texts of Advertising Communication, URL: https://www.sgu.ru/sites/default/files/journals/izvestiya/pdf/2013/12/13/08_amiri.pdf (2013) (in Russ.)

18. M.R. Babikova, Verbal iconic precedent in modern Russian nationalist discourse, Ekaterinburg, 193 (2020) (in Russ.)

19. Yu.I. Detinko, R.I.Grigoriev, Interpretation of precedent visual images in British political discourse] (2019), URL: https://cyberleninka.ru/article/n/interpretatsiya-pretsedentnyhvizualnyh-obrazov-v-britanskom-politicheskom-diskurse/viewer (in Russ.)

20. L. Mardieva, T. Shchuklina, "Text violence" (Forming the corpus of precedent visual texts), in Philology and culture, №1(59), 224-229 (2020) (in Russ.)

21. N.N. Andreeva, E.A. Serova, Formation of the cultural linguistics competence of foreign students of the art college, Contemporary issues of the the art college, in Contemporary issues of the humanities: journal of scientific study publications, No. 04,7-9 (2017) (in Russ.) 